\title{
TATA-Binding Protein-Associated Factor 172
}

National Cancer Institute

\section{Source}

National Cancer Institute. TATA-Binding Protein-Associated Factor 172. NCI Thesaurus.

Code C18185.

TATA-binding protein-associated factor 172 (1849 aa, $207 \mathrm{kDa}$ ) is encoded by the human BTAF1 gene. This protein is involved in transcriptional regulation. 